\title{
XVIII. Report on the conversion of soft iron into cast steel by means of the diamond. Read in the French National Institute, Thermidor 26, year 7
}

\section{Guyton}

To cite this article: C. Guyton (1799) XVIII. Report on the conversion of soft iron into cast steel by means of the diamond. Read in the French National Institute, Thermidor 26, year 7 , Philosophical Magazine Series 1, 5:17, 89-93, DOI: 10.1080/14786449908677122

To link to this article: http://dx.doi.org/10.1080/14786449908677122

曲 Published online: 18 May 2009.

Submit your article to this journal $₫$

Џll Article views: 3

Q View related articles $₫$ 
which ferved them as a vehicle, did not at firt alter its purity, being intimately connected with it ; but they neverthelefs exifted, and produced in its highelt regions the multiplied halos, parafelena and parhelia obferved that year. The heat increafing, and the earth continuing to furnifh exhalations in proportion to the preceding humidity, thefe were communicated to the atmofphere in a manner almoft infenfible : but the atmofphere being at length faturated, thefe exhalations underwent new decompolitions; ftorms were formed, the atmofphere was cooled, and fuffered to efcape a part of thefe exhalations, which feil again towards the carth, and in one day Europe was covered with a dry fog *. Local circumftances, in regard to moifture, winds, and clouds, exempted certain places from it for fome time. The earth, however, continuing to furnifh exhalations, and thefe being: united to thofe which the atmofphere, as we may fay, had depofited, defcending and afcending thunder were feen till the exhalations of the earth and the atmofphere were confumed. The atmofphere being gradually purified, and the fource of the exhalations exhauted, the earth ceafed to be convulfed.

XVIII. Report on the Converfion of Soft Iron into Caft Steel by means of the Diamond. Read in the Frencb National Inftitute, Tbermidor 26, Year 7. By C. Guy tox $\uparrow$.

1

$\mathrm{HE}$ Clafs will recollect the account which I gave of the grand experiment of the combuftion of the diamond in oxygen gas in the focus of the lens of Tfchirnhaufen, and the new facts which I thence deduced refpecting the true nature of the diamond; plumbago, which is its oxyd in the firft degree; carbon, which is its oxyd in the fecond degree; and the carbonic acid, which is the produce of its complete oxy.

* The fame fog, I prefume, took place in America, where there had been great complaint of drought for eight years: It was not feen in the open fea, becaufe it was abforbed by the water! for this reafon it did not appear in countries where the $\mathrm{kky}$ was overfpread with clouds.

+ From the Annalis de Cbimie, No. 92 .

VoL. V. 
genation. They fumefted to our brother, C. Clouct, the idea of fearching for a comfrimation of a new kind, by trying to make foit iron pals to the fate of Reel by cementation with the diamond.

It has hitherto been confidered as certin, that iron doeg not melt but by paffing to the fiate of ftecl or caft iron. But in what fate does the carbon enter into that combination? It might be conjectureil, that it is in the ftate of plunbago, or oxyd of the firlt degrce; fince that which is feparated by acids exhibits the brilliant blacknefs and incombutibility which form its principal charasters. Hence fome were inclined to conciude, that the carbon entered into this union in the flate of an oxidule; that confequently the carbon employed in the cementation of fieel began by teoxsdating itfelf to a certain degree. This was even in fome meafure proved; as the carbon employed for this operation was indeed found to have a more brilliant afpect, and nearly refifect incincration, like carbon in a mals burnt in clofe veffels. But if carbon really burns in the cementation of iron, it onght to difengage from it oxyen gas. This is a queftion which I have culcawered to refolve by experiment.

I cemented fma!! bits of iron in a porcelain retort, which in the preceding operation had received a vitreous coating, and which confecuently was no longer permeable to air. Thefe fragments wers all furrounded, on every fide, by charcoal of becch pulveritid, and very diry. The retort was put into the reverberating fumace, and a tube connected to it and carried unter a receiver filled with mercury. There was difengaged a quantity of claftic fluid, compofed of carbonated hydrogenous gas and carbonic acid gas, the laft of which was at firt only $O \mathrm{I}^{\mathrm{I}}$ in bulis; towards the midrle of the experiment, $0^{\circ} 1 ;$; and at the end, $0^{\circ} 15$.

The converion of iron into fteel being found only little advanced, after three hours and a half expofure to the fire, we put the fame iron and the fame carbon again into the retort, and expofed it to the heat of a threc-blaft-furnace. This time there was only a very fmall quantity of gas; but it was fiill carbonated hylrogenous cas mixed with carbonic acid gas, and always with the fame progrefion of the latter; 
which made at nift only 0.7 of volume, while the laft portions contained $0^{\circ}$ 2. The iron on this occafion was converted into fteel, and even the fragments had united by a commencement offufion.

It was very probable that a part of the carbonic acid, collected in this operation, might have been formed at the expence of the remaining carbon and with difengaged oxygen; but the conftant prefence of the hydrogen only ferved to indicate the difficulty of freeing the catcon entirely from the laft portion of water it contained. I flall here take occafion to obferve, that this experinente feens not at all reconcileable with the opinion of fome chemifts, that hydrogen has more affinity than carbon for oxygen: an opinion which they found on this circumitance, that carton is precipitated, in Volta's eudiometer, when a mixture of oxygen gas and carbonated hydrogen gas is made to detonate, if a quantity of oxygen fufficient to acidify the two bafes has not been employed. I fay, that this affinity was not exerted in my experiment: for it cannot be loubted that the temperature was high enough to reproduce water by the union of the oxygen and hydrogen; and we can here fee nothing which conld decide a preference of the oxygen for the carbon.

Thefe confiderations feemed to me fufficient to create a new intereft in regard to the experiment propoled by $\mathrm{C}$. Clouet. I did not hefitate, therefore, to employ in it one of the diamonds preferved in the cabinet of the Polytechnic fchool, according to the leave granted by the Council ; being perfuaded that if it difappeared in the operation, merely by expofure to a bigh temperature, in contact with iron, without the accelfion of the air or any other oxygenating fubtance, the fact thereby eftablifhed would leave no room to regret having facrificed it.

Citizen Clonet had himfelf prepared a fmall crucible of foft iron, forged on purpofe out of picked heads of nails. Its form was a folid of eight planes. (Plate II. fig. 3). It was thut by a fopper of the fame iron well adjufted. (Fig. 4.)

This crucible was to be placed in a Heffian crucible, furnifhed with a cover well luted. This was all the apparatus for the experiment. I cannot give a botter idea of the 

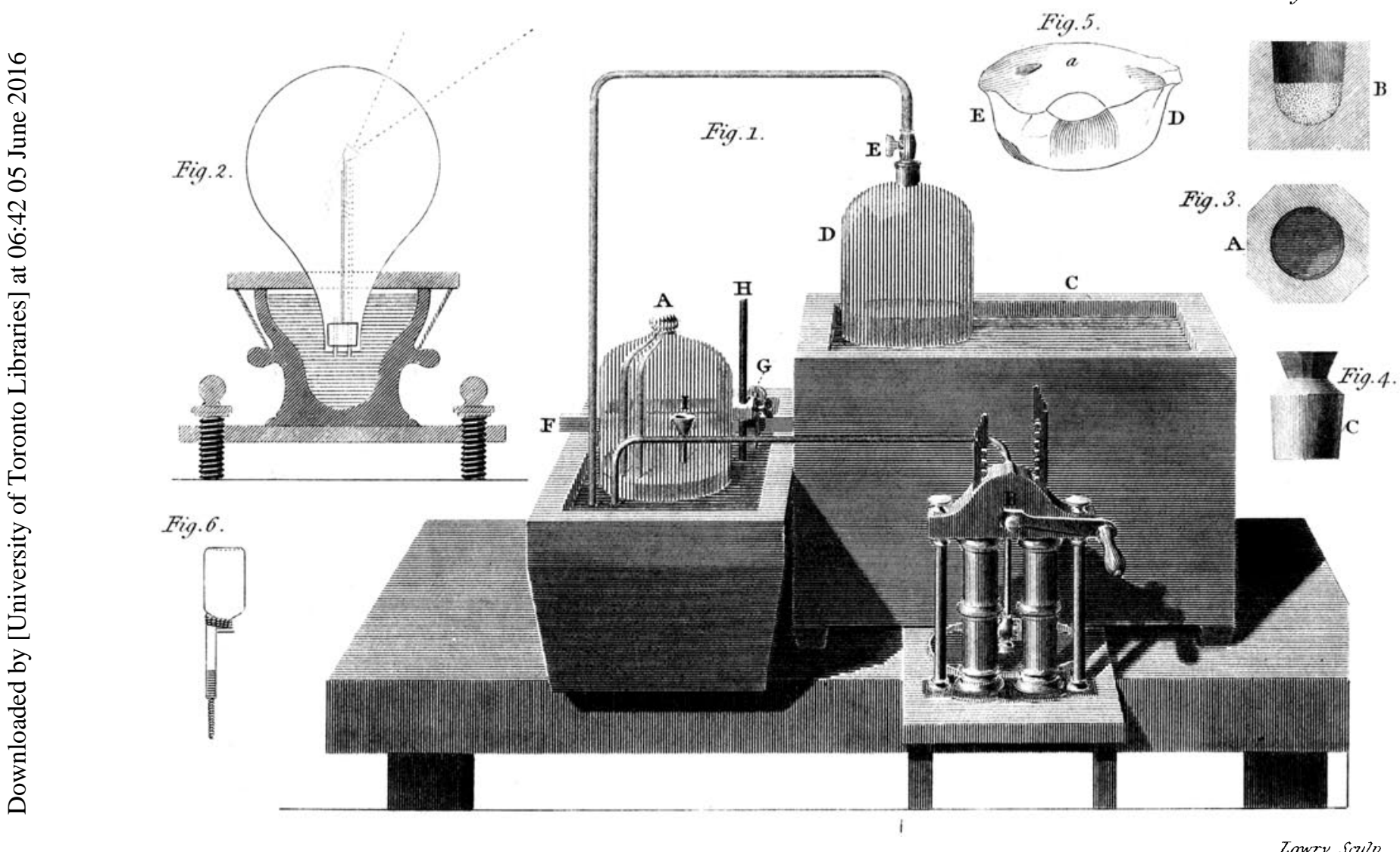
refult than by the report drawn up by C. Clouet, Welter, and Hachette.

Report of the Experiment made at the Polytecbnic Scbool, Tbermidor 2.5, Year 7, refpecting the Converfion of Iron into Steel by the Diamond.

"The diamond employed weighed 907 milligrammes. As it did not entirely occupy the crucible, we filled it with filings of the fame iron as that of which it was formed. The crucible was thut by its iron ftopper, which was forcibly thruft home, that as little air as. poffible might remain in the infide.

"The crucible and ftopper weighed together - $\quad 55.8$

"The iron filings which covered the diamond - 2

"Total weight of the iron furrounding the diamond $\overline{57.8}$ "After having cut off the excefs of the ftopper*, the crucible was placed alone, and without the addition of any furrounding matter, in a very fmall Heffian crucible, and the latter in a fecond crucible of the fame earth; but the fpace between the two latter crucibless was filled with filiceous fand free from all ferruginous particles. In the laft place, the large crucible was luted with earth arifing from pounded crucibles and unbaked clay, and the whole was expofed about an hour to a three-blaft-forge fire.

"The whole being cooled, we found, in the interior Heffian crucible, the iron converted into an ingot of caft fteel. (See fig. 5) It formed, with the ftopper and filings, but one round mafs well terminated, fome few globules excepted, which were detached, and which weighed only 884 milligrammes.

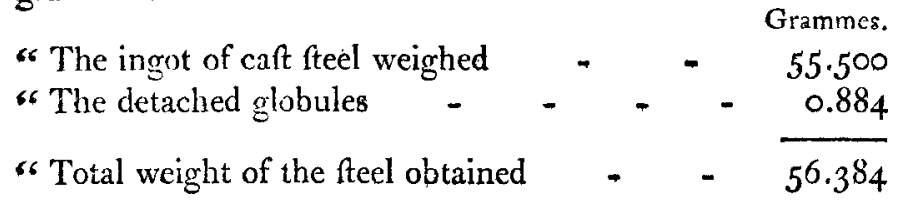

* This porrion of the ftopper, as well as the remainder of the ingot of which the crucible was formed, were fubjested to the Clafs for infpection, in order to afcertain the nature of the iron employed. 
"The iron and the diamond weighed, before the operation, 58.707 grammes; from which it follows that there was a lofs of iron about 2.423 grammes. This iron had given to the Heffian crucible the colour of plumbago.

" (Signed) Clouet, Welter, Hachette."

The fufion of the iron being fo far perfect as to thew on its furface the rudiments of the moft beautiful cryftallifation, it is not poffible to think that any part of the diamond could have remained in the infide untouched, or that it was not in the moft intimate fate of combination. The difference of the fpecific gravity oppofes fuch an idea*.

Thus the diamond difappeared by the affinity which iron exercifed on it by the help of the high temperature to which they were both expofed, in the fame manner as a metal difappears in the allay of another metal.

The diamond, therefore, has furnifhed here the fame principle as carbon, fince the product of the union has the fame properties.

The converfion into fteel is not doubtful. The ingot having been polithed on a lapidary's wheel, a drop of weak nitrous acid immediately produced a dark-grey fpot, abfolutely like that exhibited on Englifh caft fteel, and on caft fteel produced by the procefs of $\mathrm{C}$. Clonet. Thofe who have often tried fteel by this kind of proof, long ago pointed out by Rinmann, had occafion to remark, that the fpot of caft fteel, though very fenfible, is however lefs black than that of fteel made by cementation, which depends perhaps on the different degree of oxydation of the carbon which they have taken in.

\section{Explanation of the Figures.}

A, fig. 3, (Plate II.) is the plan of the iron crucible. $\mathrm{B}$, a fection of this crucible. C, fig. 4 , the ftopper of the crucible. D,E, fig. 5 , ingot of caft fteel feen in perfpective. The fpot formed by the nitric acid on the polifhed part is reprefented at $a$.

* Some perfons having expreffed a defire to fee the infide of the ingot, it was broken on the anvil, which was not effeded without feveral blows from a very large hammer. It divided itfelf into two fragments, which were exhibited at the next fitring. The fracture appeared perfectly uniform, and of the molt beautiful grain. 